\title{
THE LEADER OF THE NEW GENERATION: HUMBLE, CONNECTOR AND CONSCIOUS
}

\author{
Marius Calin Benea
}

DOI: https://doi.org/10.31410/ITEMA.2019.117

\begin{abstract}
Romania has few authentic leaders. And a lot of imagined leaders. Although the managers and entrepreneurs of today have access to profile information and an elite of specialists to advise them on leadership, few are willing to make the transformation from the native concept of ,, boss" to the one as an authentic leader. And fewer are those who then internalize in depth the concepts learned in the dedicated coaching programs. We have chosen to oppose this pessimistic reality at the other extreme, that of the humble leader. In counterpart of the paradigm formed by bosses, managers, leaders or directors with a function that gives them power. This paper debates the concept of humble leader, often confused with the humble or modest leader.
\end{abstract}

Keywords: Leadership, Humility, Learning.

\section{INTRODUCTION}

$\mathrm{D}$ gital transformation is complex and dynamic. Technological changes happen exponentialy, combinatorial and recursively, which entails profound and rapid changes. Therefore, we cannot predict the future starting from the past, because the future will not be any longer an extension of the present. Thus, the digital transformation and its implications for leadership and organizations must be addressed holistically.

There is great need for leadership and new leadership is needed.

The causes that increase the need for skills of leadership are:

- The world is very complex and the information is active and a lot. Understanding reality and filtering the information requires critical thinking. All these are a source of stress; therefore, we need people to help those who need to reinvent themselves and regain performers.

- Competition is fierce, because there is no geography anymore.

- The work environment is multigenerational as a result of performance in medicine, of mentality change and of economic pressures. At work four generations will meet with mentality, needs and different characteristics. Thus, leaders must create a culture of diversity.

Therefore, there is a great need for competent and performant leaders. And today, performance in leadership is reached by humbleness, consciousness and connection.

„Politehnica” University Timişoara, Faculty of Engineering Hunedoara, Revoluţiei 5, cod 331128, Hunedoara, Romania 


\section{MANY MAY CONTEST HUMBLENESS AS BEING A QUALITY OF A LEADER}

The universe of small and large companies has all kinds of leaders: appointed, self-styled, or simply LEADERS. We'll stop at the characteristics of the last category because it is the most valuable. For them everyone "fights":

- Natural positive attitude, balanced, cooperative, opened, valorized;

- Empathy, the capacity to mobilize people (project connector), to take quick decisions, to designate and delegate clear tasks to their teammates;

- Firmness, coherence, vision, inspiration;

- Resistance, tolerance and moderation in crisis situations;

- The power to listen and understand the needs and expectations of those their lead;

- The generosity to teach the others what you know that might help them make progress.

Many may contest humbleness as a leader's quality. He must be strong, invincible, and just to lead. And yet ... the way in which a leader relates to the power he has will always create the difference. The one that holds so many tools to lead people and remain aware of his primary role, which is to act in the service and in the interest of others, will be hard to beat!

From a realistic perspective, the management board of a large company will hesitate to hire a leader with such a human face.

In the absence of professional assessments within the leaders of multinational companies, medium or small, it is hard to identify this rare quality. In the wider area of leaders that I admire in this direction, I think of Jacques Attali, a prominent theorist in economics and social sciences, writer, first director of the European Bank for Reconstruction. A contemporary thinker of great strength, that with humbleness and the strength of his mind, he devotes for years the activity to some causes global concerns, such as environmental protection.

This type of leader is successful simply because it is excellent at what he does and has a very good relationship with his ego. No need to write his title on all doors, does not put big picture hallways, does not feel the need to say "I'm your boss, I'm right!" His success is only an attribute, the value of his work lies in the fulfillment which feels directly contributing to progress of the company and its people.

The present education system of factory type cannot cope with the knowledge-based economy. And here, in Romania, the younger generation has enormous potential. The anachronistic system in which the young learn, their family life poor in transmitting moral values, models, general knowledge, responsibility and engagement, misses from the start this potential. With exceptions, of course. Therefore, it is becoming increasingly difficult to identify talents, to train them for professional performance and leadership. All seek leaders, few manage to find them.

\section{THE MAIN ROLE OF A LEADER IS TO BE THE KEEPER OF THE COMMON GOOD}

Humbleness is, indeed, often equated with modesty or, at least, with submissive behavior. From this perspective it is incompatible with management. Human groups need leaders, it is a deep need, atavistic, transmitted by genes from one generation to another. Need is not absurd. There 
have existed in past times a number of natural experiments of some micro-companies built in extreme situations: the shipwrecked. For someone who reads the history of hundreds of shipwrecks whose histories are known, begin to emerge quite clear some models.

The evolution of these micro-communities, always in limit situations, is very different, radically different. Some of them manage very well in the survival game. Others don't, most of their members perish. Very few are found themselves in the middle. The difference between the two extremes is always the same: reporting on general human social rules and a respected leader, but not authoritarian. The lack of presence of a domineering, oppressive leader or of leadership, always led to the disappearance or drastic reduction of communities.

A good leader, however, cannot be neither humble nor submissive, because then he no longer acts as a leader. He must, however, understand, first, what is that role. Many leaders see themselves as a unique source (or main) of power and authority of the group, owners of all decisions, the source of vision of the future and of ways of action. He is the model of the heroic leader. If they retire from this position, these leaders do it based on delegation, they give to others from their power, with discretion and implicit understanding that they can take it back at any time. This leading behavior causes addiction from others, passivity or sometimes rebellion and conflict. It can give good results, but is totally dependent on the quality of the leader and his ability to keep order in the group.

But this isn't, in fact, the role of a leader, not this of leader people really need. The main role of a leader is to be guardian of the common good. Is the person who keeps the community alive, gathers people around each other, keeps and maintains human social values, distinguishes between good and evil, defends common morality? The leader is the one who gives power and cohesion to the community and greatly increases its transmitting capacities to perform and survive in difficult situations. In such a united community, difficulties are obstacles to overcome, they unite and gather. In a community led in an authoritarian way the difficulties are excuses to diminish efforts, they disperse people. From here the completely different results they obtain.

A leader who assumes this role, of catalyst for community, is a leader that leads from the inside, is a leader in the literal sense of the word. Latin, as Romanian, defined well this role: leads, takes with him, gathers people around him and leads from the middle of them. From this position, such a leader does not perceive himself as a hero on a pedestal. Moreover, he doesn't seek and does not want this position because he knows that there can no longer exercise this purpose as well. He understands that he is not superior to others, but their catalyst. In this key must be understood, in fact, humbleness.

In the Christian culture, humbleness often has religious and monastic connotations. The reason for this is that its Teacher is the first and best example of the subject: "Jesus was neither humble nor submissive nor naive. When it was necessary, He knew to be fierce and sharp. But He was never the head of his followers, but their source of well and wiseness. And these qualities changed the world." 


\section{THE AUTHENTIC LEADER HAS THE COURAGE TO CLIMB DOWN FROM THE PIEDESTAL AND TO ADMITT THE FACT THAT HE HAS DOUBTS}

Leadership has always been closely linked to success and success to the results you get. Which obviously must be positive. The projects I have undertaken in recent years, remembered me Voltaire's saying "the success which does not have followings does not mean anything". Because, in fact, if you don't have someone to share the joy of a great result, what good to strive to get it? I think the essence of the new generation leader actually means not only to get the people to follow your plan, but also to share with them the satisfaction of success. And because success is, somehow, the end of the road you go through with the team, you must first learn to listen, that is to be humble. To know how to unite the energies of all and put them to work as a whole, means to connect the individual energy to the target of the group. That means to be a connector.

And finally, to be aware means to understand that without your team you would have failed in achieving the goal, so basically to understand that success is for each member. There was much talk in recent years, in public, about the differences between a leader and a boss and the results obtained in the two situations. Leader is not only the one who assumes responsibility for both success and failure, leader is the one that takes time to listen to his people. And to achieve this, the leader must step down from the pedestal. He must meddle with his team to sit at the same table with them, observe them and to listen to them. And to admit, when it is appropriate, that he is a man and that he makes mistakes just like them.

There are such leaders in Romania in general entrepreneurs who have started to work side by side with their teams and who never forgot from where they left. In the world, some examples, have drawn my attention - Dalai Lama is one of them, Nelson Mandela is another example and I think we could include here Elon Musk. This kind of leader relates to success through the benefits brought to the people that they have represented and through the positive changes they have generated in the societies to which they belonged. The courage that they had, that to descend from the pedestal and recognize that they have doubts, that although they don't know all the answers they still do not give up, are attributes that have made them the most admired, most respected most followed people. These leaders are the ones who had imprinted new attributes to the Napoleon type of leadership which we all knew. As society and economy have their own dynamics, the same is with leadership.

The digital age means another type of connection, is to use machines to see better the people, to know better, to optimize the processes. Basically, with the help of the technology, you can form a team whose members can be anywhere in the world, but can work as if they are in the same office.

With technology, you can discover the man in your team faster than ever before. The leader becomes more a connector of interests, of objectives and needs of his team members.

To understand the new generation, including future leaders, the first who should be involved are parents and teachers, by active listening, giving up templates such as "do as I did" or "I know better". Give them the freedom to express, to reveal the creativity. To empower them and give them options or to explain the options and risks and let them choose. Responsibility of every act or activity at school is to prepare them for responsible job or business they will have at adulthood. 


\section{A HUMBLER WORLD, ESPECIALLY IN THE BUSINESS AREA, WOULD BE A BETTER WORLD}

One research reference in the study of organizational leadership is the one by Jim Collins, described in the book "Good to Great: Why Some Companies Make the Leap ... And Others Do not ". Collins studied 11 companies in top 1000 richest ones that had performance below average for 15 years and then another 15 years above average.

What made possible this jump performance was due to the leadership changes. Collins talks about competitiveness without fear accompanied at the same time, by another ingredient, which may seem paradoxical, namely humbleness. Further research shows that employees who work for humble leaders, without desire for self-promotion and pointed to see themselves as resources to facilitate team performance are more involved and remain longer in the company.

In my work experience with leaders from different organizations in Romania, multinational and big entrepreneurials, I found that better retention and the desire of people in the company to submit additional effort to achieve the results are possible because these leaders share the merits with all others and thus creates a sense of trust in others. Often there is no link between confidence and actual competence, and not because there are not enough realistic people, but because most see themselves better than they really are.

Being humble in business means being able to share the success with the team, to relate to success in the plural, to take responsibility for what goes less well, to be open to feedback, to be able to pull ahead and to recognize those who you work with, to behave properly, fairly, to perceive yourself as a resource for the team you drive, to not assume special privileges, believing you can do anything and that you are entitled to everything.

Low self-esteem, the feeling of insecurity, emotional immaturity is correlated with the desire to be the center of attention, to be seen, supported by others, validated. Therefore, often, in business, histrionic behavior, seductive, manipulative may mask a need to verify that "you're good enough".

The leadership based on humility model seemed taken, until recently, from the biblical stories. In terms of collective mindset, in the capitalist business environment, it was cooler to be charismatic, knowing-all, seductive, bold, aggressive etc. If we read through the articles from 10-15 years ago, we will find out that at that time, the discourse about what leadership means was associated with the glorification of some features such as "sociability", "confidence", "charisma" etc. The first useful exercise for any leader, especially for a charismatic one, is to look in the mirror and if he sees perfection, he should ask and listen to feedback from colleagues and team. There are also advantages of the trust in oneself:

1. You feel good to think you are better than others, whether it is perhaps only an illusion;

2. This illusion helps (up to a point) to convince the others that you are more valuable than you really are.

The organizations must begin to understand and recognize what really matters to make performance to see clearly what is the pattern of behavior of leaders validated by employees and that leads to success. Leadership is the ability to form and maintain teams to achieve performance, not the ability to stand out and get as many privileges for oneself. A humble world, especially in the sphere of business, and also in society would be a much better world. 


\section{THE SUCCESSFUL LEADER IS THE MOST DETERMINED AND ADAPTABLE PERSON ON EARTH}

Internationally, I see humble leaders in Queen Elizabeth II of Great Britain (, I know that I have a female body, but I have the heart and courage of a King”), Nelson Mandela (,,Brave people are not afraid to forgive for the sake of peace"), Mother Teresa, the universal symbol of leading peace and love (,, beware that all who come to you leave better and happier").

In Romania, the masterly example of a humble leader, connector, conscious, wise is Queen Maria of Romania (,In the years of pain I learned to pray”).

I believe that the Romanian leader is one of the most valuable in the world - I refer only to those who made the revolution and changed in good everything they touched and not for a moment the kind of leader abusive, domineering, dictator. In Romania, the leaders emerged with the fall of communism and were stated in a country that did not even exist in the vocabulary words manager, entrepreneur, market economy, leadership, capital, business.

So, the digital age, as any transformation is for successful leaders a new challenge, a new path for development, innovation and differentiation. They embrace change, whatever it may be, and live fully this state. A true leader sees beyond the symptoms and seeks the causes of problems, taking into account the idea of „Change yourself and you will change the world”.

When we no longer blame everything that happens when we will overcome the victim condition of an educational model or system, when we will see the greatness and wonder of life in everything around us, when we will look and act consciously - in present moment - making new choices of high vibration, as is our divine being, with kindness, compassion, respect for everything around us and when we will embrace change as the most beautiful answer to life, then we will become leaders of our own lives and we will be able, through our model, to inspire, to challenge and to form real leaders.

\section{FUTURE RESEARCH DIRECTIONS}

The new challenges of leadership in the digital economy - Based on the words of Pearl Zhu: "In a world of well-defined problems, directors are required to exercise influence over volatility, manage uncertainty, simplify complexity, and resolve ambiguity in the 21st-century digital environment" we indicate the factors ensuring future leadership performance: performance, growth mindset, data mining, business talent, digitization.

To have talent for business (business acumen) means not only understanding and knowing the business environment, but also having the ability to make choices depending on the context, not based on habits and automatism. The context is changing, and if we consider it, we will make performance.

In emergency situations, when we are under pressure, we act on instinct. So, learning must be accompanied by transformation.

Thus, a future leader must increase the speed and agility of transformation, to support leadership for change, to support collaboration and create growth through learning and organizational culture. 
In this way one can pass from independence to interdependence, from control to connection, from individual to group and from alliances to network.

Agility is based on respect, courage, openness, concentration and dedication.

\section{CONCLUSION}

You cannot do business without character. First you need to create values, which then have to support skills. Among the inadequate skills there are: individual competition through the destruction of ideas, procrastination and the habit of freezing (fight or flight became fight or freeze) - which generates depression and anxiety.

Being adaptable does not mean to develop safety mechanisms, but to create value.

Leadership skills are more awaken than developed. The role of the leader is to awaken existing leadership skills in people. He can do that by being himself the model of leadership that they seek and ensure them their proper context so that the necessary transformation can be produced in them.

\subsection{Leadership key elements.}

The leader must not lose touch with the people he leads. His role is to create characters and develop people. And for that he has to understand the times and adapt the learning to the future.

\section{REFERENCES}

Collins, J.C., (2001). Good to Great: Why Some Companies Make the Leap... and Others Don't, New York, U.S.A, Publisher: William Collins

Pearl, Z., (2018). Digitizing Boardroom: The Multifaceted Aspects of Digital Ready Boards, Morrisville, North Carolina, U.S.A. Publisher: Lulu.com 